J. Perinat. Med. 6 (1977) 244

\section{CAP, HCS and urinary estriol measurements in risk pregnancies - A comparative study}

\author{
Gunnar Rydén, Bertil Kågedal
}

Department of Obstetrics and Gynecology (G.R.), Department of Clinical Chemistry (B.K.), University Hospital, Linköping, Sweden
In recent years many different methods have been published for evaluating the feto-placental unit which per se indicate that at present no test fulfil the qualifications of being a suitable test for that purpose. Among the feto-placental function tests which have been studied, measurements of urinary estriol excretion, estimations of human chorionic somatomammotrophin (HCS) and cystine aminopeptidase (CAP) in maternal plasma at present seem to be the most widely used methods. Urinary estriol assays are generally accepted as an advisable method in monitoring the feto-placental unit during the last trimester. Concerning the clinical significance of HCS and CAP assays the opinions are however more varying. It seemed therefore desirable to compare the value of all three methods for evaluating the feto-placental function during the last trimester. The issue of the study was to examine if HCS and CAP assays are comparable to estriol assays in predicting the condition of the infant at birth and to study if a combination of tests might give more accurate information concerning the feto-placental unit than only one test.

\section{Material}

\subsection{Normal pregnancy (reference group)}

Only healthy women with uncomplicated pregnancies who subsequently gave birth to healthy single infants weighing more than 2500 grams were included. They were followed by serial sampling
Curriculum vitae

GUNNAR RYDÉN was born in Sweden 1932. He studied medicine at the Karolinska Institutet, Stockholm 1951-1959, was employed at the Department of Surgery and the Department of $\mathrm{Ob}$ stetrics and Gynecology, Sabbatsberg's Hospital between 1959-1968 and graduated in obstetrics and gynecology 1966 at the Karolinska Institutet. Since

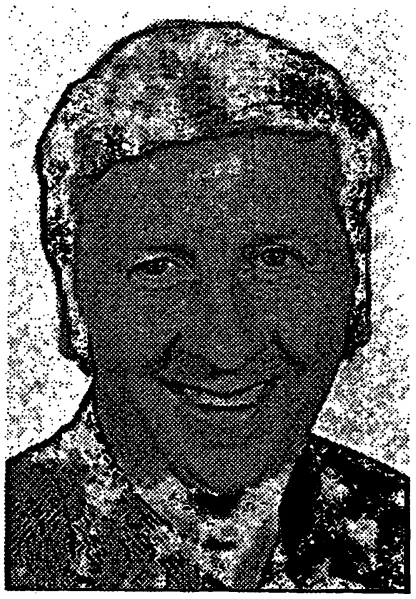

1968 Gunnar Ryden is assistant professor at the Department of Obstetrics and Gynecology, Linköping University. His main research has been about drug effects on uterine motility, the metabolism of oxytocin, studies on the origin of oxytocinase and the clinical significance of cystine aminopeptidase estimations in pregnancy.

usually every second week from between the 28 th to $32 \mathrm{nd}$ week of pregnancy until delivery. The total number of patients in this group was 45 .

In order to study the day-to-day variation, two samples were taken with 24 hours intervals in a number of patients, totally 61 duplicate samples.

\subsection{High risk pregnancy}

The study has been performed during the time period 1. 1. 1973 to 31.12 .1974 . During this period the total number of deliveries was 4343 , 
with a perinatal mortality of $1.4 \%$. The material studied, consists of 656 women which were judged as risk-pregnancies. In these patients one or more analyses of all three parameters have been performed from the 36 week of pregnancy. Usually one to two assays have been performed each week. In some risk pregnancies daily estriol assays have been performed on clinical indications but only those assays have been included in the study where HCS and CAP estimations have been performed simultaneously. Patients with $\mathrm{Rh}$-immunization and twin pregnancies have been excluded from the material. The material has been divided into two groups.

Normal infant group (540 patients): Pregnancy with no fetal complications at delivery. APGAR score $\geqslant 7$ one minute after delivery. Normal birth weight.

Distressed infant group (116 patients): Pregnancy with fetal complications at delivery according to the following criteria:
A. Cardiotocographic recordings indicating fetal distress during delivery and APGAR score $<7$ one minute after delivery (21 patients).

B. Pregnancy operatively terminated due to fetal distress (60 patients of which 37 were delivered by cesarean section and 23 by vacuum extraction).

C. Birth weight $<2$ S.D. from the mean according to gestational age (35 patients).

\section{Methods}

Daily urinary output of estrogens were measured according to HAINSWORTH and HALL [8]. The determinations were performed on a TECHNICON autoanalyzer. Cystine aminopeptidase (CAP) in serum was measured at $37^{\circ} \mathrm{C}$ with the method described by PEETERS [16] using 1-cystine-bis-paranitroanilide as substrate. Human chorionic somatomammotrophin (HCS) was measured according to LINDBERG et al [12] with use of the Phadebas HCS Kit from Pharmacia Diagnostics.

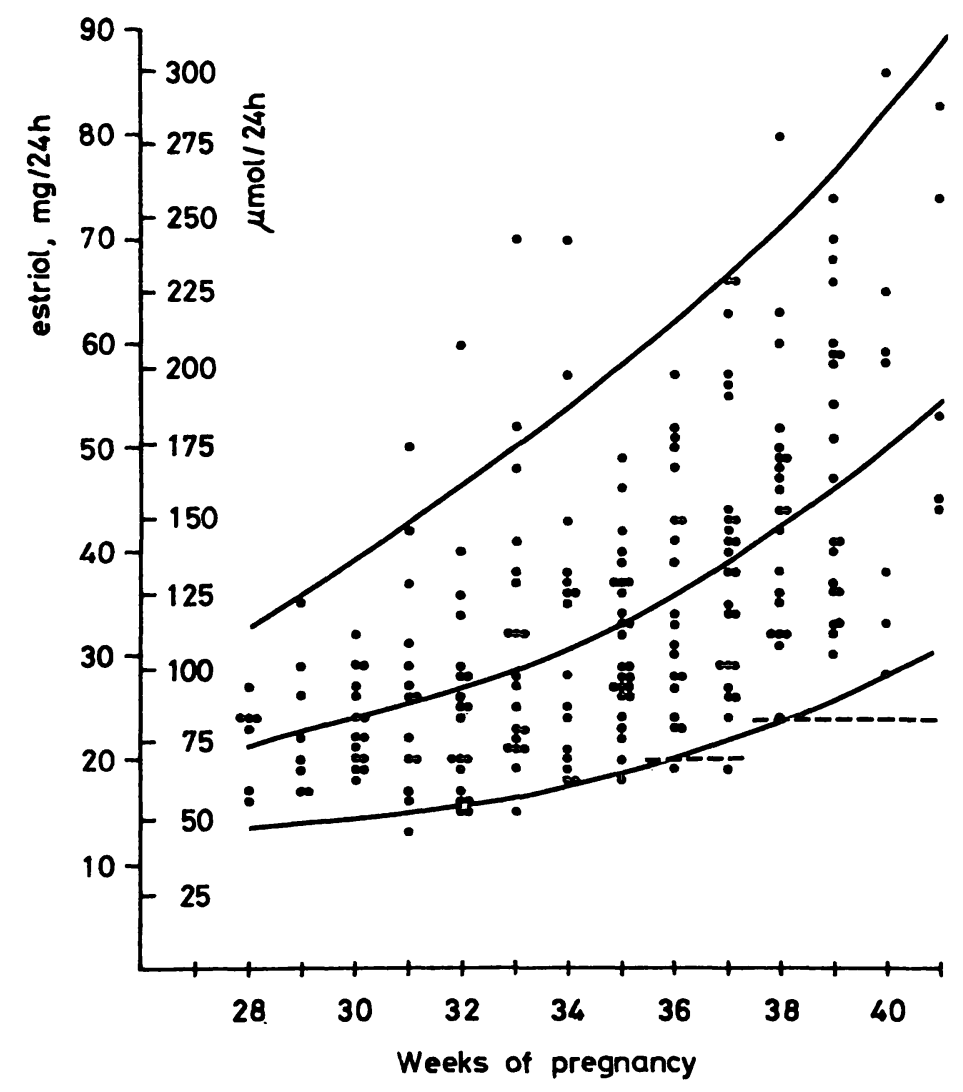

Fig. 1. Urinary excretion of estriol in 45 normal pregnancies. Each woman collected urin every second week until delivery. Solid lines are 5-, 50- and 95- percentiles. Dotted lines corresponds to the reference levels used. Results are given both as $\mathrm{mg} / 24 \mathrm{~h}$ and $\mu \mathrm{mol} / 24 \mathrm{~h}$. 


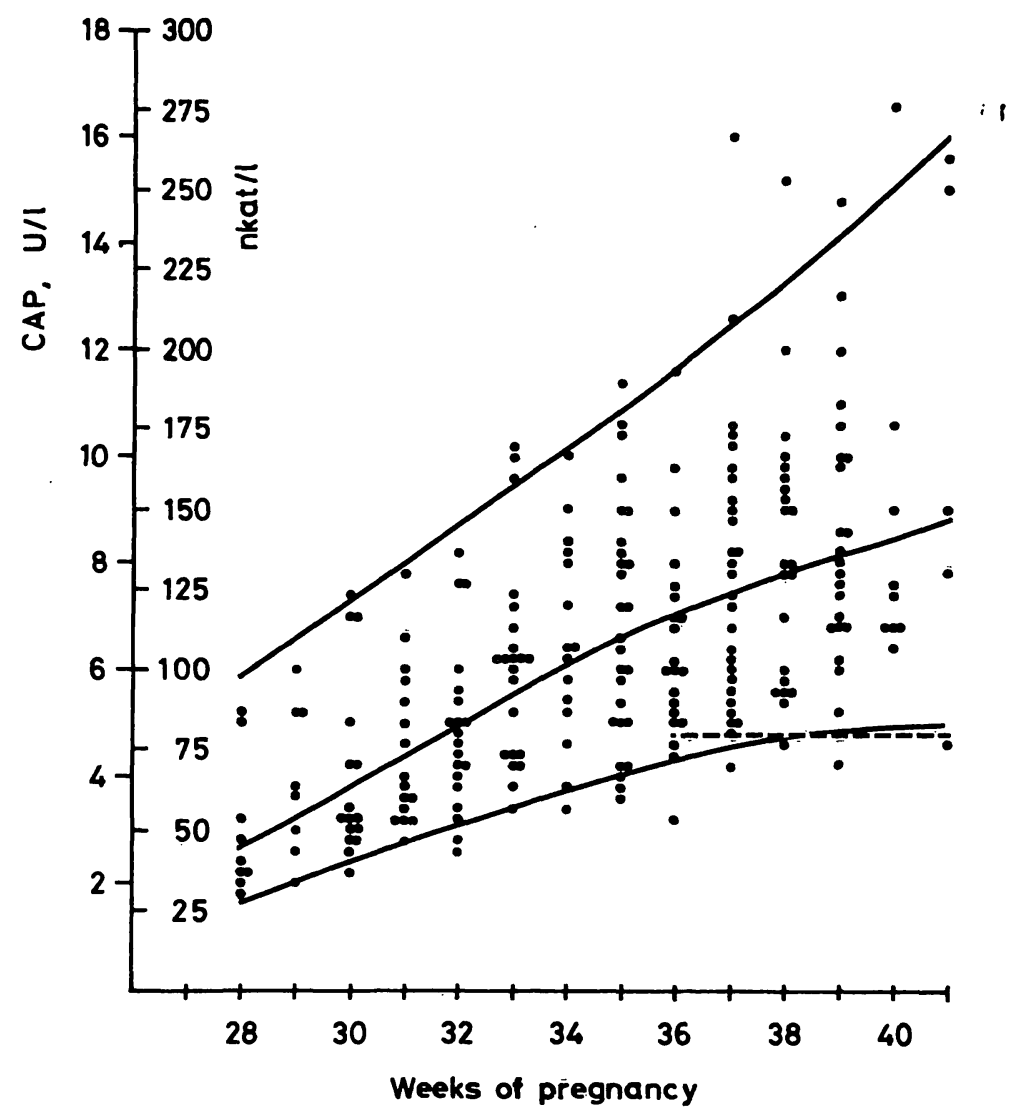

Fig. 2. Serum concentration of cystine aminopeptidase, CAP, in 45 normal pregnancies. Samples were taken at 2 weeks interval. Solid lines are 5-, 50- and 95- percentiles. Dotted line gives the reference level used. Results are given both as $\mathrm{U} / 1\left(\mu\right.$ mole $\left.\times \min ^{-1} \times 1^{-1}\right)$ and nkat/1 (nmole $\left.\times \mathrm{s}^{-1} \times 1^{-1}\right)$.

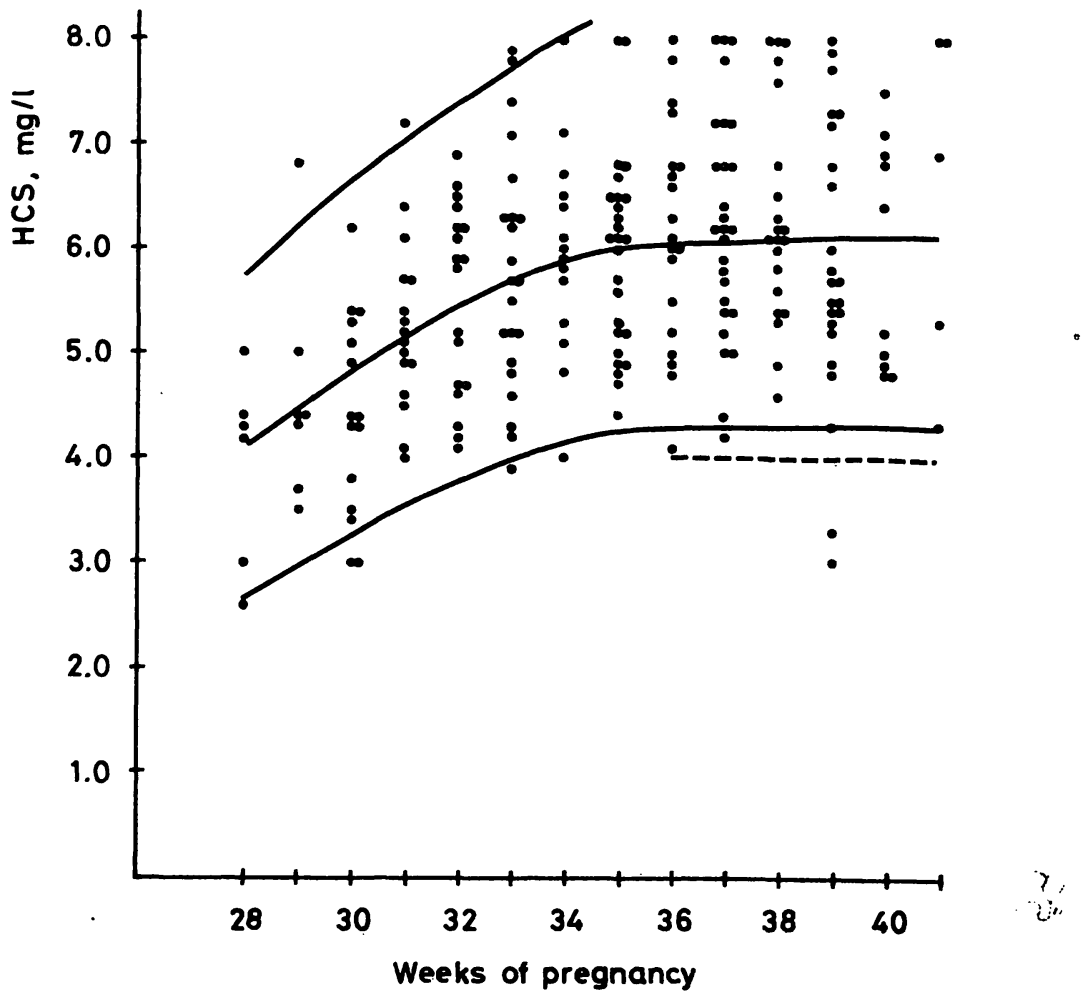

Fig. 3. Serum concentration of human chorionic somatomammotrophin (HCS) in 45 normal pregnancies. Samples were taken every second week until delivery. Values above $8 \mathrm{mg} / \mathrm{l}$ are given as $8 \mathrm{mg} / 1$. Solid lines are 5-, 50- and 95- percentiles. Dotted line gives the reference level used. 
Low biochemical parameters have been defined as follows:

HCS $<4 \mathrm{mg} / \mathrm{l}$ serum from 36 week of pregnancy CAP $<80$ nkat $/ 1$ ( $4.8 \mathrm{U} / \mathrm{l})$ serum from 36 week of pregnancy

Urinary estriol excretion

$<70 \mu \mathrm{mol}(20 \mathrm{mg}) / 24$ hours during week $36-37$ $<84 \mu \mathrm{mol}(24 \mathrm{mg}) / 24$ hours from 38 week of pregnancy

\section{Results}

\subsection{Normal pregnancy (reference group)}

The results obtained in serial samples during normal pregnancies from the 28 th week of pregnancy are seen in Fig. 1-3.

The day-to-day variation calculated as the coefficient of variation was for CAP assays $8.5 \%$, for HCS assays $7.3 \%$ and for estriol assays $16.0 \%$.

\subsection{High risk pregnancy}

The frequency of low biochemical parameters in the normal and distressed infant group are presented in Tab. I. A statistical analysis using FISHER's exact test [2] demonstrates that all three parameters are valuable in predicting fetal complications in risk pregnancies. Estriol assays seem to be somewhat superior to CAP and HCS in this respect, the difference ishowever not statistically significant.

Tab. I. The incidence of low biochemical parameters in the normal and in the distressed infant group.

\begin{tabular}{|c|c|c|c|c|c|}
\hline \multirow{2}{*}{$\begin{array}{l}\text { Number of } \\
\text { patients }\end{array}$} & \multicolumn{2}{|c|}{$\begin{array}{l}\text { Normal } \\
\text { infants } \\
540\end{array}$} & \multicolumn{2}{|c|}{$\begin{array}{c}\text { Distressed } \\
\text { infants } \\
116\end{array}$} & \\
\hline & $\mathrm{n}$ & $\%$ & $\mathbf{n}$ & $\%$ & \\
\hline Low estriol & 47 & 8.7 & 35 & 30 & $P<0.001$ \\
\hline Low CAP & 29 & 5.4 & 27 & 23 & $P<0.001$ \\
\hline Low HCS & 30 & 5.6 & 21 & 18 & $P<0.001$ \\
\hline
\end{tabular}

In order to study if combination of tests give more information than only one parameter the frequency of low biochemical parameters in the normal and the infant complication group with different combinations of the biochemical tests have been cal-
Tab. II. The incidence of low biochemical levels with two or three combined tests.

\begin{tabular}{|c|c|c|c|c|}
\hline \multirow{2}{*}{$\begin{array}{l}\text { Number of } \\
\text { patients }\end{array}$} & \multicolumn{2}{|c|}{$\begin{array}{l}\text { Normal } \\
\text { infants } \\
540\end{array}$} & \multicolumn{2}{|c|}{$\begin{array}{c}\text { Distressed } \\
\text { infants } \\
116\end{array}$} \\
\hline & $\mathrm{n}$ & $\%$ & $\mathrm{n}$ & $\%$ \\
\hline \multirow{4}{*}{$\begin{array}{l}\text { Low CAP or } \\
\text { estriol } \\
\text { Low CAP or HCS } \\
\text { Low HCS or } \\
\text { estriol } \\
\text { Low CAP/HCS or } \\
\text { estriol }\end{array}$} & 73 & 14 & $\begin{array}{l}47 \\
20\end{array}$ & 41 \\
\hline & 52 & 9.6 & 38 & 33 \\
\hline & 73 & 14 & 44 & 38 \\
\hline & 93 & 17 & 52 & 45 \\
\hline
\end{tabular}
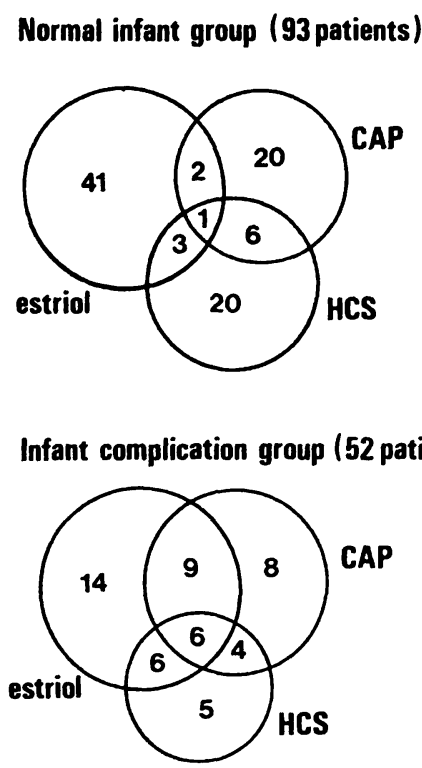

Fig. 4. The distribution of low biochemical values among 540 patients in the normal infant group and among 116 patients in the infant complication group.

culated. Provided that at least one biochemical parameter should be low, the results obtained are shown in Tab. II.

The value of different combinations of the biochemical test is also demonstrated in Fig. 4. Estriol combined either with CAP or HCS add further 26 patients with low values in the normal infant group (540 patients) whereas in the complication group (116 patients) the addition of CAP and HCS predict 12 and 9 new cases respectively.

A statistical analysis was performed using FiSHER's exact test in order to evaluate if estriol assays combined either with HCS or CAP gave more information than only estriol assays. The results 
obtained showed that estriol combined with CAP gave a significant increase in the number of detected distressed infants $(P=0.003)$. Similar results were also found concerning HCS combined with estriol compared to estriol assays $(P=0.04)$. A combination of all three tests did not significantly increase the number of detected risk deliveries compared to the combination estriol - CAP or estriol - HCS. According to the results obtained, a combination of the serum assays CAP - HCS predicted the same incidence of distressed infants as urinary estriol assays alone.

\section{Discussion and conclusion}

A number of studies have repeatedly confirmed that the quantity of maternal estriol excretion in urine is a reliable index of the function of the fetoplacental unit. The method has however some disadvantages, mainly the inaccuracy of the 24 hours sampling. Even with careful urine collection the individual day-to-day variation is rather pronounced (the coefficient of variations was $16 \%$ in the present study). Many reports also indicate that estriol assays not always reflect the condition of the feto-placental unit $[6,15,19]$, and much research has during the last decade been directed towards new methods for evaluating the fetoplacental unit.

In recent years much attention has been directed towards the determination of HCS as a possible mean of monitoring the placental function $[1,11$, $13,20,21]$. Among the numerous studies on this subject a recently published paper by SPELLACY et al. [21] is the most convincing concerning the clinical value of HCS-assays. In a large randomized controlled prospective study they demonstrated the usefulness of routine prenatal HCS measurements in the management of high risk pregnancies. They obtained a significantly reduced fetal death rate in the group controlled by HCS assays compared with a control group.

Concerning CAP assays the results are more conflicting. WATSON et al. [23], who compared the usefulness of CAP, HCS, heat-stable alkaline phosphatase (HSAP) and, 17- $\beta$-estradiol in plasma and urinary estriol excretion found HSAP and CAP to be the least sensitive indicators of feto-placental dysfunction in twelve patients studied. In eight of these patients, however, only mild feto-placental dysfunction was present, ahd it is therefore difficult to evaluate their results. CURZEN and VARMA [7] who compared CAP and urinary estriol assays concluded that CAP was of no value in predicting the condition of the feto-placental unit. Other authors $[3,4,9,17,19,22]$ have found that CAP assays are justified as a valuable test alongside estimation of estriol excretion in judging the fetoplacental unit during the last trimester. The various results obtained by different authors, can partly be explained by varying assay procedures for CAP. Especially studies performed using l-cystine-di- $\beta$ naphtylamide as substrate might give different results depending on the assay procedure [18]. Most of the previous studies have also been performed on small clinical materials and without a statistical analysis of the results.

The limits chosen for normal and low values concerning the different chemical tests might also influence the results obtained by different authors. Regarding HCS, most previous authors have used values of HCS less than $4 \mathrm{mg} / \mathrm{l}$ as an indication of decreased placental function and it seemed therefore reasonable to use the same limit in the present study. Concerning CAP and estriol assays a statistical analysis of the results obtained in the reference group demonstrated that the figures were not normally distributed. The limit for normal values regarding $\mathrm{CAP}$ and estriol was therefore chosen corresponding to the 95 percentile in the reference group. In that way about the same number of low values was obtained in the normal infant group for all three methods studied (Tab. I).

Comparative studies using all three parameters are scanty. KRISTENSEN et al. [5] compared HCS, CAP and urinary estriol excretion in pregnancies complicated with essential hypertension and preeclampsia. They concluded that a combination of all three tests contribute to a more reliable information in pregnancies complicated with preeclampsia. The present study confirms that all three tests are valuable in predicting the condition of the feto-placental unit in risk pregnancies. When comparing all three methods it seems that estriol assays are somewhat better than HCS and CAP assays in predicting the condition of the infant at birth, the 
difference is however not statistically significant. Nevertheless it must be emphasized that estriol assays which reflect the condition of the whole feto-placental unit cannot be substituted by HCS or CAP assays which only reflect the condition of the placenta. If estriol assays are combined with CAP or HCS assays a somewhat better reliability is obtained. The same conclusions have recently been made by SCHMID [20] comparing estriol and estriol-HCS assays.

Urinary estriol assays seem to give the most reliable information concerning the condition of the fetus among the methods used in the present study. Estriol assays are however inconvenient to use as a screening procedure for detecting risk pregnancies, partly because of the practical problems with the urine sampling, partly because of the large day-today variation. The first problem can be overcome with plasma estriol assays. It is however still questionable if plasma assays of estriol is more reliable than urinary assays $[10,14]$. HCS and CAP assays are more suitable for routine use in large scale and if they are used simultaneously at least

\section{Summary}

Cystine aminopeptidase (CAP) and human chorionic somatomammotrophin (HCS) activity in maternal serum and urinary estriol excretion have been followed simultaneously in normal and risk-pregnancies to study if CAP and HCS are comparable to estriol assays in predicting the condition of the fetus at birth and to study if a combination of tests give more accurate information concerning the fetoplacental unit than only one test. The results were as follows:

\section{Normal pregnancy}

The material consists of 45 patients which were followed every second week from the 28-32 week of pregnancy until term with serial assays of CAP, HCS and urinary estriol. (Fig. 1-3).

The coefficient of variation was for CAP 8.5 per cent, for HCS 7.3 per cent and for urinary estriol 16.0 per cent.

\section{High-risk-pregnancy}

The material has been divided into two groups, a normal infant group consisting of 540 patients and a distressed infant group consisting of 116 patients.

Low biochemical parameters have been defined as follows: HCS $<4 \mathrm{mg} / 1$ serum from 36 week of pregnancy, CAP < 80 nkat/1 (4.8 U/1) serum from 36 week of pregnancy, urinary estriol excretion $<70 \mu \mathrm{mol}(20 \mathrm{mg}) / 24$ hours the same number of distressed fetuses will be detected as with estriol assays, HCS and CAP estimations are very easy to perform and need only a venous blood sample which can be taken on out-patient clinics and CAP-assays need rather ordinary equipment. Even if both tests are reflecting the condition of the placenta it seems preferable to use them simultaneously as they are overlapping each other to a rather small extent, which may indicate that they are reflecting different parts of the placental function. As CAP and HCS only assess the conditions of the placenta the risk pregnancies detected in this way should thereafter be controlled using more sensitive indicators of fetal well-being, i.e. estriol assays, ultrasound measurements of the biparietal diameter and cardiotocographic recordings in order to estimate the optimal time for delivery. Management of pregnancies in this way might decrease the perinatal mortality further, especially the number of prenatal deaths which at present are responsible for a large part of the perinatal deaths in full term pregnancies. week $36-37$ and $<84 \mu \mathrm{mol}(24 \mathrm{mg}) / 24$ hours from 38 week of pregnancy.

The frequency of low biochemical parameters in the normal infant group was $\mathbf{8 . 7 \%}$ for estriol, $5.4 \%$ for CAP and $5.6 \%$ for HCS assays. The corresponding figures in the distressed infant group was 30,23 and $18 \%$ respectively. The frequency of low biochemical parameters in the normal and the infant complication group with different combinations of tests has also been calculated. The results obtained demonstrated that estriol combined either with CAP or HCS gave a significant increase in the capacity to predict fetal complications compared to estriol assays alone. A combination of all three tests did not significantly increase the number of detected distressed fetuses compared to a combination of two parameters.

The following conclusions can be made:

All three methods are valuable in predicting fetal complications. Estriol assays seem to be somewhat superior to CAP and HCS in this respect. Urinary estriol assays should be used as the primary biochemical test for evaluating the feto-placental unit. If estriol assays are combined with CAPor HCS an increase in the number of detected distressed fetuses was obtained compared to estriol assays alone. If CAP was combined with HCS this combination was at least as informative as estriol assays alone, and this combination should preferably be used as screening-test to detect pregnancies where placental insufficiency may occur.

Keywords: Cystine aminopeptidase, fetal distress, human chorionic somatomammotrophin, placental function test, risk pregnancy, urinary estriol excretion. 


\section{Zusammenfassung}

CAP, HCS and Östriolbestimmungen im Urin bei Risikoschwangerschaften - Eine vergleichende Studie.

Die mütterlichen Serumaktivitäten der Cystinaminopeptidase (CAP) und des menschlichen Chorionsomatomammotrophin (HCS) sowie die Östriolausscheidungen im Urin wurden bei normalen und Risikoschwangerschaften simultan gemessen. Ziel der Studie war es zu untersuchen, ob CAP und HCS mit den Östriolanalysen vergleichbar sind hinsichtlich der Vorhersage des Zustandes des Feten bei der Geburt; weiter sollte untersucht werden, ob eine Kombination der Teste eine genauere Information über die fetoplazentare Einheit vermittelt als ein Test alleine. Folgende Resultate wurden erzielt.

\section{Normale Schwangerschaft}

Das Krankengut bestand aus 55 Patientinnen. Bei diesen wurde jede zweite Woche, beginnend von der 28.-32. Woche der Schwangerschaft bis zum Termin, Serienuntersuchungen von CAP, HCS und Urinöstriol durchgeführt (Fig. 1-3). Der Variationskoeffizient für CAP betrug $8.5 \%$, für HCS $7.3 \%$ und für das Urinöstriol $16.0 \%$. i!

Risikoschwangerschaft

Das Krankengut wurde in zwei Gruppen aufgeteilt, eine Gruppe von 540 Patientinnen mit gesundem Kind und eine Gruppe von 116 Patientinnen mit beeinträchtigten Neugeborenen.

Die tiefen biochemischen Parameter wurden folgendermaßen definiert: HCS $<4 \mathrm{mg} / 1$ Serum für die 36 . Schwangerschaftswoche, CAP $<80$ nkat/1 im Serum für die 36. Schwangerschaftswoche und Urinöstriol $<70 \mu \mathrm{Mol} / 24$ Std. für die 36. -37 . Woche und $<84 \mu \mathrm{Mol} / 24$ Std. ab der 38. Schwangerschaftsw oche.
Die Häufigkeit tiefer biochemischer Parameter betrug in der normalen Gruppe $8.7 \%$ für die Östriolbestimmungen, $5.4 \%$ für die CAP-Aktivität und 5.6\% für die HCSSpiegel. Die korrespondierenden Zahlen für Kinder mit distress betrugen 30,23 und $18 \%$. Es wurde auch die Häufigkeit des Auftretens von tiefen biochemischen Meßwerten in der Vergleichsgruppe und in der Gruppe mit kindlichen Komplikationen berechnet beim Vorliegen verschiedener Kombinationen an Testen. Die erzielten Resultate zeigen, daß die Östriolbestimmung in Verbindung mit CAP oder HCS einen signifikanten Zuwachs in Hinblick auf das Vorhersagevermögen fetaler Komplikationen mit sich bringt im Vergleich zu der Östriolbestimmung alleine. Eine Kombination aller drei Teste ließ die Anzahl der Feten mit erkanntem distress nicht signifikant ansteigen im Vergleich zu einer Kombination von nur zwei Meßgrößen.

Die folgenden Schlüsse können gezogen werden:

Alle drei Methoden eignen sich für die Vorhersage fetaler Komplikationen. Die Östriolbestimmung scheint diesbezüglich gewisse Vorteile vor der CAP und HCS-Bestimmung zu haben. Die Urinöstriolbestimmungen sollten daher als erster biochemischer Test verwandt werden, um die Funktion der fetoplazentaren Einheit zu prüfen. Wenn die Östriolbestimmung mit der CAP und HCS-Bestimmung kombiniert wird, ist im Vergleich zur Verwendung der Östriolbestimmung alleine eine Zunahme der Anzahl richtig erkannter fetaler Notsituationen gegeben. Wird die CAP-Bestimmung mit der HCS-Analyse kombiniert, so ist diese Verbindung zumindest ebenso informativ wie die Östriolbestimmung alleine; diese Kombination sollte daher vorzugsweise als screening-Test eingesetzt werden, um Schwangerschaften $\mathrm{zu}$ diagnostizieren, bei denen eine Plazentainsuffizienz auftreten kann.

Schlüsselwörter: Cystinaminopeptidase, fetaler Distress, menschliches Chorion somatomammotrophin, Placentafunktionstest, Risikoschwangerschaft, Urinöstriolausscheidung.

\section{Résumé}

Les mesures de CAP, HCS et d'oestriol urinaire dans les grossesses à risque - Une étude comparée

Nous avons procédé à l'observation simultanée dans des grossesses normales et à risque de la «cystine aminopeptidase» (CAP) et de l'activité de somato-mammotrophine chorionique humaine (HCS) dans le sérum maternel et l'excrétion d'oestriol urinaire afin d'étudier si la CAP et la HCS peuvent servir, au même titre que les tests d'oestriol, à prédiagnostiquer l'état du foetus à la naissance et si l'application combinée de plusieurs tests fournit davantage d'indications sur l'unité foeto-placentaire que le recours à un seul test. Nos études à ce sujet ont donné les résultats suivants:

\section{Grossesse normale}

Le matériel concerne 45 parturientes qui ont été suivies toutes les deux semaines entre la 28-32ème semaine de la grossesse et le terme par des séries de tests de CAP, HCS et oestriol urinaire (Fig. 1-3).

Le coefficient de variation a été de $8,5 \%$ pour la CAP, de $7,3 \%$ pour la $\mathrm{HCS}$ et de $16,0 \%$ pour l'oestriol urinaire.

\section{Grossesse à risque élevé}

Le matériel a été divisé en deux groupes, un groupe infantile normal de 540 patients et un groupe infantile dyspnoïque de 116 patients.

Les paramètres biochimiques bas ont été définis comme suit: $\mathrm{HCS}<4 \mathrm{mg} / 1$ de sérum de la 36 ème semaine de grossesse, CAP $<80$ nkat/ $1(4,8 \mathrm{U} / 1)$ de sérum de la 36 ème semaine de grossesse, Excrétion d'oestriol urinaire $<70 \mu \mathrm{mol}(20 \mathrm{mg}) / 24$ heures semaine $36-37$ et $<$ $84 \mu \mathrm{mol}(24 \mathrm{mg}) / 24$ heures 38 ème semaine de grossesse.

La fréquence des paramètres biochimiques bas dans le groupe infantile normal a été de $8,7 \%$ pour l'oestriol, de $5,4 \%$ pour la CAP et de $5,6 \%$ pour la HCS. Les courbés correspondantes du groupe infantile dyspnoïque ont été respectivement de 30,23 et $18 \%$. On a également calculé la fréquence des paramètres biochimiques bas dans les deux groupes en associant diversement les tests. Les résultats obtenus ont montré que l'oestriol combiné soit avec la CAP ou avec la HCS sert d'indicateur beaucoup plus précis dans le prédiagnostic des complications foetales 
que lorsqu'il est testé seul. Mais une association des trois tests ne s'est pas révélée beaucoup plus significative que celle de deux paramètres.

En conclusion, on peut affirmer que les trois méthodes sont valables pour le prédiagnostic des complications foetales. Les tests d'oestriol semblent être d'un intérêt plus grand à cet égard que la CAP et la HCS. Les tests d'oestriol urinaire devraient donc être utilisés commes tests biochimiques primaires pour l'évaluation de l'unité foeto-placentaire. Une association des tests d'oestriol avec CAP ou HCS a permis de détecter un plus grand nombre de foetus non sainsque les tests d'oestriol seul. L'association de CAP et de HCS a été au moins aussi instructive que les tests d'oestriol seul et devrait être appliquée de préférence comme test sélectif pour dépister les grossesses à insuffisance placentaire éventuelle.

Mots-clés: cystine aminopeptidase, dyspnée foetale, excrétion d'oestriol urinaire, grossesse à risque, somatomammotrophine chorionique humaine, test de la fonction placentaire.

\section{Bibliography}

[1] BERle, P., B. HASElMAYeR, H. PlAMBECK: Vergleichende Untersuchungen von CTG und hormonalen Parametern bei der Diagnostik der Placentainsuffizienz. Arch. Gynäk. 219 (1975) 426

[2] BROWNLEE, K. A.: Statistical theory and methodology in science and engineering. John Wiley \& Sons Inc. New York 1965

[3] CHAPMAN, L., E. SILK, A. SKUPNY, E. A. TOOTH, A. BARNES: Spectrofluorimetric assay of serum cystine aminopeptidase in normal and diabetic pregnancy compared with total oestrogen excretion. J. Obstet. Gynaec. Brit. Cwlth. 78 (1971) 435

[4] CHRISTENSEN, A.: Hormone and enzyme assays in pregnancy. III. The placental cystine aminopeptidase and the urinary oestrogens in pregnancies complicated with essential hypertension, mild or severe pre-eclampsia. Acta endocr. (Kbh) 76 (1974) 353

[5] CHRISTENSEN, A., D. FR $\emptyset$ YSHOV, P. FYLLING: Hormone and enzyme assays in pregnancy. IV. The human chorionic somatomammotrophin, placental cystine aminopeptidase, progesterone and the urinary oestrogens in pregnancies complicated with essential hypertension, mild or severe pre-eclampsia. Acta endocr. (Kbh) 77 (1974) 344

[6] CURZEN, P., R. VARMA: A comparison of serum heat stable alkaline phosphatase and urinary estrogen excretion in the mother as placental function tests. J. Obstet. Gynaec. Brit. Cwlth. 78 (1971) 686

[7] CURZEN, P., R. VARMA: A comparison of serum cystine aminopeptidaseand urinary estrogen excretion as placental function tests. Amer. J. Obstet. Gynec. 115 (1973) 929

[8] HAINSWORTH, I. R., P. E. HALL: A simple automated method for the measurement of oestrogens in the urine of pregnant women. Clin. Chim. Acta 35 (1971) 201

[9] HENSLEIGH, P. A., K. E. KRANTZ: Oxytocinase and placental function. Amer. J. Obstet. Gynec. 107 (1970) 1233

[10] KÜNZIG, H. J., K. H. GÖTZ: Plasmakonzentration von Östron, Östradiol und Östriol in freier und gebundener Form bei der normalen und pathologische Gravidität. Arch. Gynäk. 219 (1975) 439

[11] LETCHWORTH, A. T., T. CHARD: Placental lactogen levels as a screening test for fetal distress and neonatal asphyxia. Lancet (1972) I 704

[12] LINDBERG, B. S., B. A. NILSSON, A. ROTH, L. YLÄNIN: Estimation of human chorionic somatomammotrophin (HCS) levels during normal pregnancy using a rapid radioimmunoassay. Upsala J. Med. Sci. 77 (1972) 129

[13] LINDBERG, B.S., B. A. NILSSON: Human placental lactogen (HPL) levels in abnormal pregnancies. J. Obstet. Gynaec. Brit. Cwlth. 80 (1973) 1046

[14] LINDBERG, B. S., E. D. B. JOHANSSON, B. A. NILSSON: Plasma levels of nonconjugated oestradiol$17 \beta$ and oestriol in high risk pregnancies. Acta obstet. gynec. scand. Suppl. 32 (1974) 37

[15] LOW, J. A., R. S. GALBRAITH, R. W. BOSTON: Maternal urinary estrogen patterns in intrauterine growth retardation. Obstet. and Gynec. 42 (1973) 325

[16] PEeters, J. A. B. M.: Automated determination of serum oxytocinase activity. Clin. Chem. 18 (1972) 563

[17] PetruCCO, O. M., K. CEllieR, A. Fishtall: Diagnosis of intrauterine fetal growth retardation by serial serum oxytocinase, urinary oestrogen and serum heat stable alkaline phosphatase (HSAP) estimations in uncomplicated and hypertensive pregnancies. J. Obstet. Gynaec. Brit. Cwlth. 80 (1973) 499

[18] RYDÉN, G.: Cystine aminopeptidase activity in pregnancy. I. A rapid method for estimation of placental function in clinical practice. Acta obstet. gynec. scand. 50 (1971) 253

[19] RYDÉN, G.: Cystine aminopeptidase activity in pregnancy. A comparison between cystine aminopeptidase activity in maternal blood and urinary oestriol excretion during pregnancy. Acta obstet. gynec. scand. 53 (1974) 341

[20] SCHMID, J.: Die Schwangerschaftsüberwachung bei plazentarer Dysfunktion. Z. Geburtsh. Perinat. 180 (1976) 21

[21] SPELLACY, W. N., W. C. BUHI, S. A. BIRK: The effectiveness of human placental lactogen measurements as an adjunct in decreasing perinatal deaths. Amer. J. Obstet. Gynec. 121 (1975) 835

[22] TOVEY, J. E.: Cystine aminopeptidase in normal and complicated pregnancies. J. Obstet. Gynaec. Brit. Cwlth. 79 (1972) 788

[23] WATSON, D., S. A. SIDDIQUI, J. E. H. STAFFORD, S. GIBBARD, V. HEWITT: A comparative study of five laboratory tests for foeto-placental dysfunction in late pregnancy. J. clin. Path. 26 (1973) 294

Received May 31, 1976. Accepted February 15, 1977.

Gunnar Rydén, M.D.

Linköping University

Dept. Obstet. and Gynec.

S-58185 Linköping, Sweden 